\title{
Investigations of Nitrogen Removal Pathways in a Biological Packed Bed Reactor Using Elementary Mass Balances
}

\author{
Antonio Albuquerque ${ }^{1}$, Jacek Makinia ${ }^{2}$, Krishna Pagilla ${ }^{3}$ \\ ${ }^{1}$ Civil Engineering and Architectural Department and C-MADE, University of Beira Interior, \\ PORTUGAL \\ ${ }^{2}$ Faculty of Civil and Environmental Engineering, Gdansk University of Technology, POLAND \\ ${ }^{3}$ Civil, Architectural and Environmental Engineering Department, Illinois Institute of \\ Technology, USA
}

\begin{abstract}
Nitrogen $(\mathrm{N})$ cycle involves a complex set of potential biochemical pathways with reactions catalyzed by different microorganisms. Elementary mass balances for COD, DO, $\mathrm{NH}_{4}-\mathrm{N}$ and alkalinity were conducted and stoichiometric relationships were investigated to explain possible pathways of the nitrogen removal mechanisms in a lab-scale submerged down flow biological packed bed (BPB) reactor. Four sets of experiments were performed by modifying the organic loading and $\mathrm{C} / \mathrm{N}$ ratio in comparison with steady-state conditions. Approximately $90 \%$ of COD and $\mathrm{NH}_{4}-\mathrm{N}$ removal occurred in two upper sections occupying $1 / 5$ of the reactor height. The elementary mass balances could not explain all the experimental results with respect to nitrogen removal and oxygen consumption by known mechanisms. The mass balance calculations, excluding the possibility of nitrification, were in general in accordance with the observations indicating no or minimal $\mathrm{NO}_{3}-\mathrm{N}$ production. The theoretical stoichiometric requirements for nitrification reaction were satisfied in 6 experiments and in another 8 experiments nitrification may have occurred, but stoichiometry was not satisfied. Using $\mathrm{C} / \mathrm{N}$ ratio as the variable, only at $\mathrm{C} / \mathrm{N}$ ratio $=10$, the predictions confirmed the possibility of nitrification in the same 3 (out of 4) assays as observed in practice. The results of this study reveal that the nitrogen transformations occurring in the studied reactor are complex and cannot be explained by simple mechanisms of microbial assimilation and nitrification.
\end{abstract}

\section{KEYWORDS}

Nitrogen removal, biological packed bed reactor, mass balances, stoichiometry

\section{INTRODUCTION}

Nitrogen compounds are among the most important pollutants as their discharge to inland and coastal waters may adversely affect water resources in several ways including contribution to eutrophication, depletion of oxygen, toxicity to aquatic environment and public health concerns. Therefore, stringent regulations concerning nitrogen removal from wastewater have been enforced in the European Union (Urban Wastewater Directive 91/271/EEC) and USA (total $\mathrm{N}=3 \mathrm{~g} \mathrm{~N} / \mathrm{m}^{3}$ in some regions, e.g. Chesapeake Bay). In order to satisfy these requirements, conventional secondary treatment systems need to be retrofitted or the treatment scheme should be expanded with tertiary polishing treatment.

Application of biological filtration to remove residual nitrogen and oxygen demand in the tertiary step can be a promising alternative to retrofitting (Jeong et al., 2006). The capital cost of adding tertiary treatment is lower in comparison with construction of a new advanced treatment system. 
Construction of biological filters does not interfere with operation of existing reactors. Moreover, maintenance is easier as there is no need for sludge recycling and a final clarifier (Hidaka and Tsuno, 2004). Grady et al. (1999) emphasized other numerous advantages of biological filtration, such as a high concentration of active biomass, good control of excess biomass, good efficiency of pollutant (carbon, nitrogen, phosphorous and pathogen) removal combined with a high filtering capacity (without separate settling facilities). Even though biofilters using organic media are known to produce efficient treatment for different types of wastewater, but the nitrogen removal mechanisms implied during biofiltration still remain not well understood (Garzon-Zuniga et al., 2005). In the study of Yu et al. (2007), the nitrogen loss and DO paradox were observed in full-scale biofilters for drinking water treatment. The observed nitrate production and DO consumption were substantially lower compared to the theoretical stoichiometric amounts required for nitrification. The authors suggested that alternate pathways other than nitrification were involved in the nitrogen transformations. For example, assimilation and denitrification were initially mentioned as two possible ways of ammonia and nitrate utilization without consuming dissolved oxygen (DO).

The combined nitrification-denitrification processes have been considered to be the most common method for nitrogen removal from wastewater (Paredes et al., 2007). Traditionally, it has been assumed that each of these two processes is attributed to different functional bacterial groups. In fact, the nitrogen cycle pattern may involve a complex set of potential biochemical pathways, as shown in Figure 1, where reactions are catalyzed by different microorganisms.

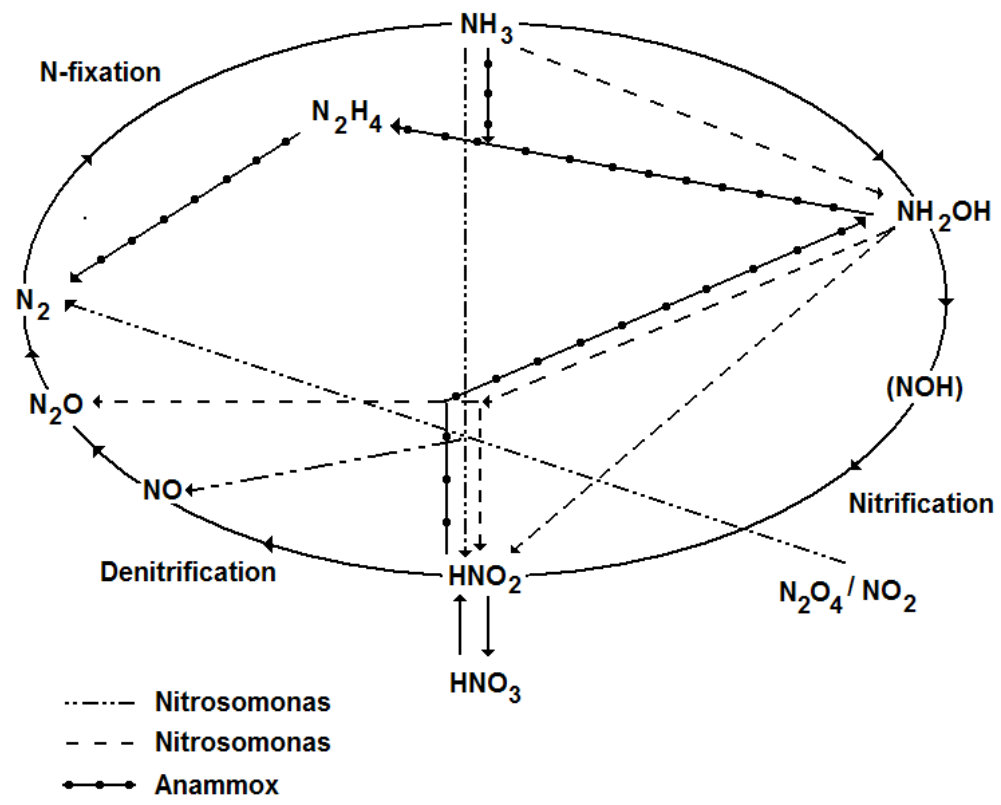

Figure 1 - Nitrogen cycle including newly discovered processes (adapted from van Loosdrecht and Salem, 2005)

Even though there are still many unknown nitrogen transformations, the discovery of microorganisms capable of oxidizing ammonia under anaerobic conditions (ANAMMOX) has greatly improved the understanding of the revised nitrogen cycle (Ahn, 2006). Moreover, it has also led to the development of novel processes that are based on partial nitrification of ammonia to nitrite combined with anaerobic ammonium oxidation. These processes include the single reactor system for high ammonia removal over nitrite (SHARON) process (sometimes followed by ANAMMOX), 
oxygen limited autotrophic nitrification-denitrification(OLAND), completely autotrophic nitrogen removal over nitrite (CANON) and aerobic/anoxic deammonification. These processes were reviewed by Schmidt et al. (2003), Khin and Annachhatre (2004), Ahn (2006) and Paredes et al. (2007).

Other nitrogen removal processes, such as heterotrophic denitrification under aerobic conditions, heterotrophic nitrification and autotrophic denitrification were also reported (Ahn, 2006). Littleton et al. (2003) evaluated the importance of novel processes including autotrophic denitrification and heterotrophic nitrification-aerobic denitrification for nitrogen removal in three biological nutrient removal activated sludge systems. The authors concluded that novel microorganisms were not substantial contributors to nitrogen removal at the plants studied. However, the systems with high biomass retention, such as a variety of biofilm reactors more appropriate for cultivating slowly growing lithoautotrophic organisms, including ANAMMOX bacteria (Ahn, 2006) are very likely. Experimental evidence suggests that the novel processes may play an important role in those systems. For example, substantial nitrogen losses, ranging from 10 to $90 \%$, were found in lab-scale rotating biological contactors $(\mathrm{RBC})$ treating ammonium rich wastewater at low $\mathrm{C} / \mathrm{N}$ ratios (Helmer and Kunst, 1998; Siegrist et al., 1998; Helmer et al. 1999, Pynaert et al., 2002). In a pilot-scale moving bed biological reactor (MBBR), the observed nitrogen losses were exceeding $90 \%$ (Helmer et al. 2001).

A convenient way of defining and understanding what occurs within treatment reactors is the mass balance analysis (Tchobanoglous et al., 2003). In biofilm reactors, global mass balances can be written at the macroscopic level based on the continuity equations over the whole system (Wanner et al., 2006). This approach was used in this study to analyze the long-term operating data for a labscale submerged down flow biological packed bed (BPB) reactor. Elementary mass balances for $\mathrm{COD}, \mathrm{DO}, \mathrm{NH}_{4}-\mathrm{N}$ and alkalinity were conducted to explain possible pathways of the nitrogen removal mechanisms in the studied $\mathrm{BPB}$ reactor.

\section{METHODOLOGY}

\section{Experimental Set-up}

The experimental set-up used in this study consisted of three major elements: refrigerated storage tank with an agitator for a feeding solution, bench-scale biological packed bed (BPB) reactor and a sedimentation tank. The BPB reactor was constructed of tubular acrylic glass of $7 \mathrm{~cm}$ internal diameter and $40.5 \mathrm{~cm}$ total packing height (Figure 2) in a downward flow configuration. A homogeneous puzzolane material with the porosity of 0.52 was used as support media for biofilm growth. The effective diameter and specific surface area of this material were $4 \mathrm{~mm}$ and 1740

$\mathrm{m}^{2} / \mathrm{m}^{3}$, respectively. The media bed was submerged $3 \mathrm{~cm}$ below the water level. Five sampling ports (P1 to P5) were provided along the height of the BPB reactor to collect effluent samples for analytical measurements. Another five ports in the same locations were connected to piezometers to evaluate variations in the hydrostatic pressure between the ports. The reactor was also equipped with an external aeration device (TetraTec AP150 pump) with the maximum capacity of $150 \mathrm{~L} / \mathrm{h}$, connected between ports $\mathrm{P} 3$ and $\mathrm{P} 4$, but the air supply system was not used during the period of this study. 


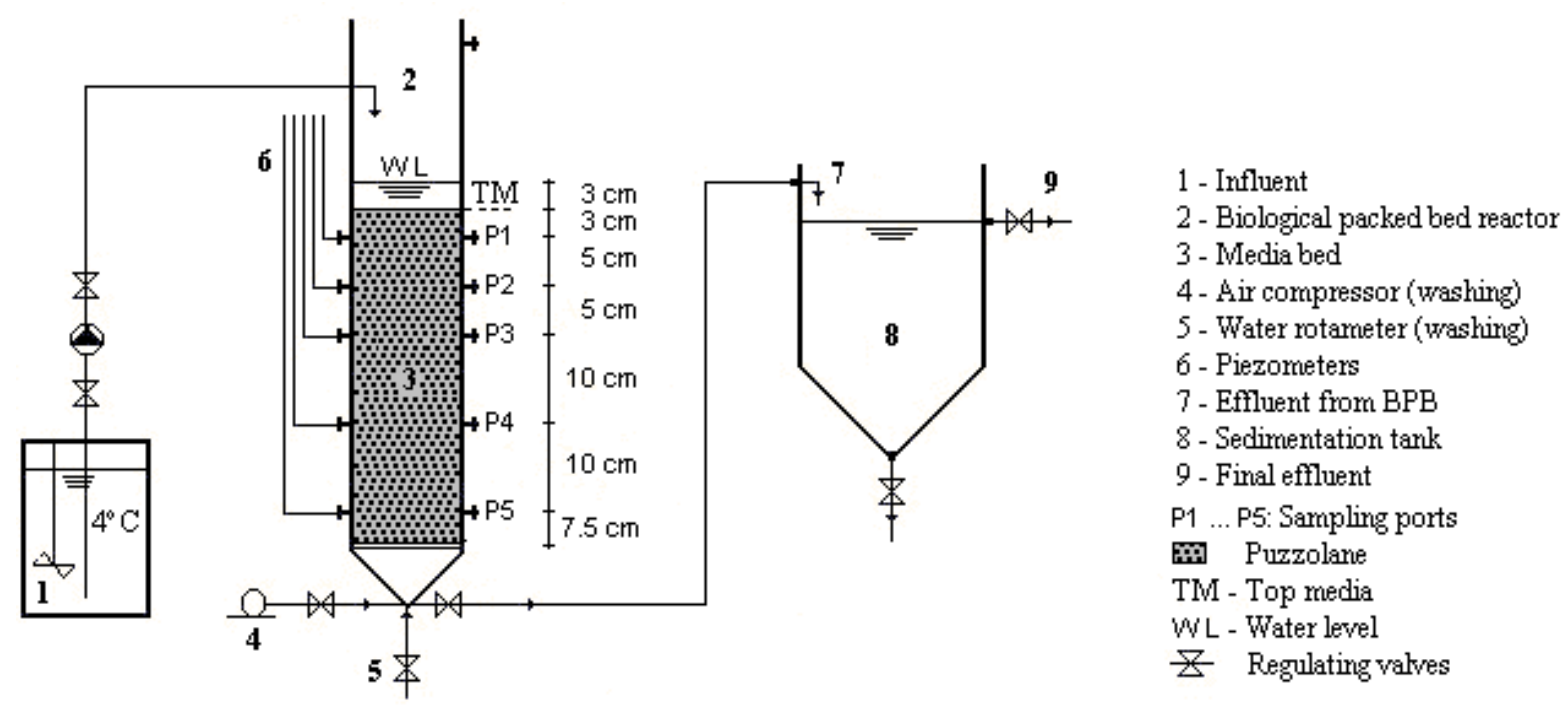

Figure 2 - Schematic illustration of the experimental set-up including the submerged BPB reactor)

\section{Feeding Solution}

The feeding solution used for colonisation and experiments included a mineral medium (buffer, magnesium sulphate, calcium chloride and iron chloride solutions), prepared as proposed by Dang et al. (1989), an oligoelements solution (according to the French standard NF EN 29439, 1993), organic carbon source (sodium acetate), and ammonia nitrogen (ammonia chloride). The concentrated mineral medium had the following composition: buffer solution $\left(8.50 \mathrm{~g} \mathrm{KH}_{2} \mathrm{PO}_{4}+\right.$ $21.75 \mathrm{~g} \mathrm{~K}_{2} \mathrm{HPO}_{4}+33.40 \mathrm{~g} \mathrm{Na}_{2} \mathrm{HPO}_{4} .7 \mathrm{H}_{2} \mathrm{O}+1.70 \mathrm{~g} \mathrm{NH} 4 \mathrm{Cl}$ per L), magnesium sulphate solution (22.50 $\mathrm{g} \mathrm{MgSO}_{4} .7 \mathrm{H}_{2} \mathrm{O}$ per L), calcium chloride solution (36.43 $\mathrm{g} \mathrm{CaCl}_{2} .2 \mathrm{H}_{2} \mathrm{O}$ per L), iron chloride solution $\left(0.25 \mathrm{~g} \mathrm{FeCl}_{3} .6 \mathrm{H}_{2} \mathrm{O}\right.$ per $\left.1 \mathrm{~L}\right)$ and oligoelements solution $\left(0.04 \mathrm{~g} \mathrm{MnSO}_{4} .4 \mathrm{H}_{2} \mathrm{O}+0.06 \mathrm{~g}\right.$ $\mathrm{H}_{3} \mathrm{BO}_{3}+0.04 \mathrm{~g} \mathrm{ZnSO}_{2} .7 \mathrm{H}_{2} \mathrm{O}+0.032 \mathrm{~g}\left(\mathrm{NH}_{4}\right)_{6} \cdot \mathrm{Mo}_{7} \mathrm{O}_{24} .4 \mathrm{H}_{2} \mathrm{O}+0.10 \mathrm{~g} \mathrm{C}_{10} \mathrm{H}_{12} \mathrm{FeN}_{2} \mathrm{NaO}_{8} .3 \mathrm{H}_{2} \mathrm{O}+$ $0.0555 \mathrm{~g}$ EDTA $\left(\mathrm{C}_{10} \mathrm{H}_{14} \mathrm{~N}_{2} \mathrm{Na}_{2} \mathrm{O}_{8} .3 \mathrm{H}_{2} \mathrm{O}\right)+0.0445 \mathrm{~g} \mathrm{FeCl}_{3} .6 \mathrm{H}$ per $\left.\mathrm{L}\right)$. The concentrated sodium acetate solution $\left(113.4 \mathrm{~g} \mathrm{C}_{2} \mathrm{H}_{3} \mathrm{O}_{2} \mathrm{Na} .3 \mathrm{H}_{2} \mathrm{O}\right.$ per $1 \mathrm{~L}$ ) had a COD concentration of $50 \mathrm{~kg} \mathrm{COD} / \mathrm{m}^{3}$ and a TOC concentration of $20 \mathrm{~kg} \mathrm{C} / \mathrm{m}^{3}$. The concentrated ammonia chloride solution $\left(76.41 \mathrm{~g} \mathrm{NH}_{4} \mathrm{Cl}\right.$ per $1 \mathrm{~L}$ ) had a $\mathrm{NH}_{4}-\mathrm{N}$ concentration of $20 \mathrm{~kg} \mathrm{~N} / \mathrm{m}^{3}$.

Under the normal operating conditions (excluding the experimental assays), the BPB reactor was fed with the synthetic wastewater with a COD concentration of $100 \mathrm{~g} \mathrm{COD} / \mathrm{m}^{3}$ (equivalent to $40 \mathrm{~g} \mathrm{C} / \mathrm{m}^{3}$ ) and the $\mathrm{C} / \mathrm{N}$ ratio $=4$. The synthetic wastewater was prepared by diluting the concentrated solutions in the following proportions: $2 \mathrm{~mL} / \mathrm{L}$ of the buffer solution, $0.2 \mathrm{~mL} / \mathrm{L}$ of the magnesium sulphate solution, $0.2 \mathrm{~mL} / \mathrm{L}$ of the calcium chloride solution, $0.2 \mathrm{~mL} / \mathrm{L}$ of the iron chloride solution, $0.2 \mathrm{~mL} / \mathrm{L}$ of the oligoelements solution, $2 \mathrm{~mL} / \mathrm{L}$ of sodium acetate solution, and $0.5 \mathrm{~mL} / \mathrm{L}$ of ammonia chloride solution. For the experiments the feeding solution composition was changed in order to obtain four different $\mathrm{C} / \mathrm{N}$ ratios in the influent $(2,4,10$ and 20) as shown in Table 1. The appropriate concentrations of $\mathrm{COD}$ and $\mathrm{NH}_{4}-\mathrm{N}$ were obtained by diluting the concentrated solutions of sodium acetate and ammonia chloride according to the volumes presented in Albuquerque (2003). The feeding solution was kept in the storage tank (ISCO FTD 220) at a constant temperature of approximately $4{ }^{\circ} \mathrm{C}$ and pumped to the $\mathrm{BPB}$ reactor through a peristaltic pump (ISMATEC MCP CA4). 
Table 1 - Operating conditions during the experimental assays

\begin{tabular}{|c|c|c|c|c|c|c|c|c|c|}
\hline Days & Assay & pH & $\begin{array}{c}\text { Temp. } \\
{ }^{\circ} \mathrm{C}\end{array}$ & $\begin{array}{c}\text { COD } \\
\mathrm{g} \mathrm{COD} / \mathrm{m}^{3} \\
\end{array}$ & $\begin{array}{c}\text { TOC } \\
\text { g C } / \mathrm{m}^{3}\end{array}$ & $\begin{array}{c}\text { Feed DO } \\
\mathrm{g} \mathrm{O}_{2} / \mathbf{m}^{3} \\
\end{array}$ & $\begin{array}{l}\text { NH4-N } \\
\text { g N/m } \mathrm{m}^{3}\end{array}$ & $\begin{array}{c}\text { Alkalinity } \\
\mathrm{g} \mathrm{CaCO}_{3} / \mathrm{m}^{3}\end{array}$ & $\begin{array}{c}\mathrm{C} / \mathbf{N} \\
\mathrm{g} \text { C/g N }\end{array}$ \\
\hline \multirow{4}{*}{$55-75$} & A1.2.1 & 7.2 & 17.2 & 153 & 62.7 & 7.7 & 3.1 & 118 & 20,2 \\
\hline & A 1.2 .3 & 7.2 & 17.5 & 101 & 41.7 & 7.8 & 2.2 & 91.3 & 19,0 \\
\hline & A 1.2 .4 & 70 & 170 & 51 & 20.6 & 77 & 11 & 85.2 & 18,7 \\
\hline & A1.2.6 & 6.8 & 17.3 & 11 & 4.2 & 7.9 & 0.23 & 58.3 & 18,3 \\
\hline \multirow{4}{*}{$75-95$} & A2.2.1 & 7.2 & 17.5 & 152 & 62.7 & 7.9 & 6.2 & 124 & 10,1 \\
\hline & A2.2.3 & 7.2 & 17.5 & 100 & 41.6 & 7.7 & 4.2 & 94.5 & 9,9 \\
\hline & $\mathrm{A} 2.2 .4$ & 7.2 & 17.2 & 50 & 20.8 & 7.8 & 2.2 & 86.3 & 9,5 \\
\hline & A2.2.6 & 6.9 & 17.6 & 10 & 4.8 & 7.7 & 0.45 & 55.1 & 10,7 \\
\hline \multirow{8}{*}{$95-135$} & A3.2.1 & 7.3 & 20.0 & 154 & 62.6 & 7.7 & 15.5 & 125 & 4,0 \\
\hline & A3.2.2 & 7.2 & 19.8 & 132 & 52.2 & 7.9 & 12.9 & 103 & 4,0 \\
\hline & A3.2.3 & 7.2 & 18.2 & 104 & 41.6 & 7.7 & 10.1 & 93.8 & 4,1 \\
\hline & A3.2.4 & 7.2 & 17.8 & 52 & 20.8 & 7.8 & 5.3 & 88.8 & 3,9 \\
\hline & A 3.2 .5 & 7.2 & 17.6 & 26 & 10.5 & 7.7 & 2.7 & 68.8 & 3,9 \\
\hline & A3.2.6 & 7.1 & 17.2 & 10 & 4.2 & 7.8 & 1.0 & 53.3 & 4,2 \\
\hline & A3.2.7 & 7.0 & 17.8 & 5 & 2.1 & 7.8 & 0.51 & 41.7 & 4,1 \\
\hline & A3.2.8 & 6.8 & 19.3 & 3 & 1.1 & 7.8 & 0.29 & 24.3 & 3,8 \\
\hline \multirow{4}{*}{$\begin{array}{l}135- \\
155\end{array}$} & A4.2.1 & 7.2 & 17.8 & 151 & 62.2 & 7.8 & 31.2 & 114 & 2.0 \\
\hline & A 4.2 .3 & 7.2 & 17.0 & 102 & 41.3 & 7.8 & 21.0 & 93.0 & 2.0 \\
\hline & A4.2.4 & 7.2 & 18.1 & 52 & 20.9 & 7.8 & 10.6 & 86.9 & 2.0 \\
\hline & A4.2.6 & 7.2 & 17.2 & 10 & 4.3 & 7.6 & 2.2 & 57.1 & 2.0 \\
\hline
\end{tabular}

\section{Operation of the Experimental Set-up}

The reactor was operated without aeration for the long term (155 days). The operation involved three phases: colonization (phase I), achieving steady state conditions (phase II), and performing experimental assays (phase III).

In phase I, the reactor was inoculated with biomass from an activated sludge system treating municipal wastewater. The colonization of the bed took approximately 15 days in a closed circuit ( 1 $\mathrm{L} / \mathrm{h}$ ) and discontinuous feeding. Approximately $38.9 \mathrm{~mL}$ and $9.7 \mathrm{~mL}$ of acetate and ammonia 
solutions, respectively, and a proportional volume of the mineral solutions were added to the reactor every $24 \mathrm{~h}$ in order to ensure the concentrations of $100 \mathrm{~g} \mathrm{COD} / \mathrm{m}^{3}$ and $10 \mathrm{~g} \mathrm{NH}_{4}-\mathrm{N} / \mathrm{m}^{3}(\mathrm{C} / \mathrm{N}=4)$. The measurements of $\mathrm{DO}, \mathrm{pH}$, temperature, TOC, $\mathrm{COD}$ and $\mathrm{NH}_{4}-\mathrm{N}$ were performed at the end of each cycle before feeding (every second day) in the influent, P2 and the effluent.

In the second phase, the reactor was operated continuously during 35 days to attain steady state conditions and determine a backwash cycle. The reactor was fed with the feeding solution $(100 \mathrm{~g}$ $\mathrm{COD} / \mathrm{m}^{3}$ and $10 \mathrm{~g} \mathrm{NH}_{4}-\mathrm{N} / \mathrm{m}^{3}$ ) at the flow rate of $1 \mathrm{~L} / \mathrm{h}$ (approximately $0.26 \mathrm{~m}^{3} / \mathrm{m}^{2} / \mathrm{h}$ ). The measurements of $\mathrm{DO}, \mathrm{pH}$, temperature, TOC, $\mathrm{COD}$ and $\mathrm{NH}_{4}-\mathrm{N}$ were performed every 2 days in the influent, $\mathrm{P} 2$ and effluent. The hydrostatic pressure was recorded daily from each piezometer.

Four series of experiments (altogether 20 assays) were performed during 105 days of phase III by modifying the organic loading and $\mathrm{C} / \mathrm{N}$ ratio in comparison with the steady-state conditions (Figure 3 ). Between the experiments, for approximately 4 days (the period required to attain steady-state conditions as shown in Albuquerque, 2003), the reactor feed was the same as that at steady state conditions (i.e. $100 \mathrm{~g} \mathrm{COD} / \mathrm{m}^{3}$ and $10 \mathrm{~g} \mathrm{NH}_{4}-\mathrm{N} / \mathrm{m}^{3}$ at the flow rate of $1 \mathrm{~L} / \mathrm{h}$ ). On the 5 th day, the operating conditions were modified for each individual experiment as presented in Table 1.

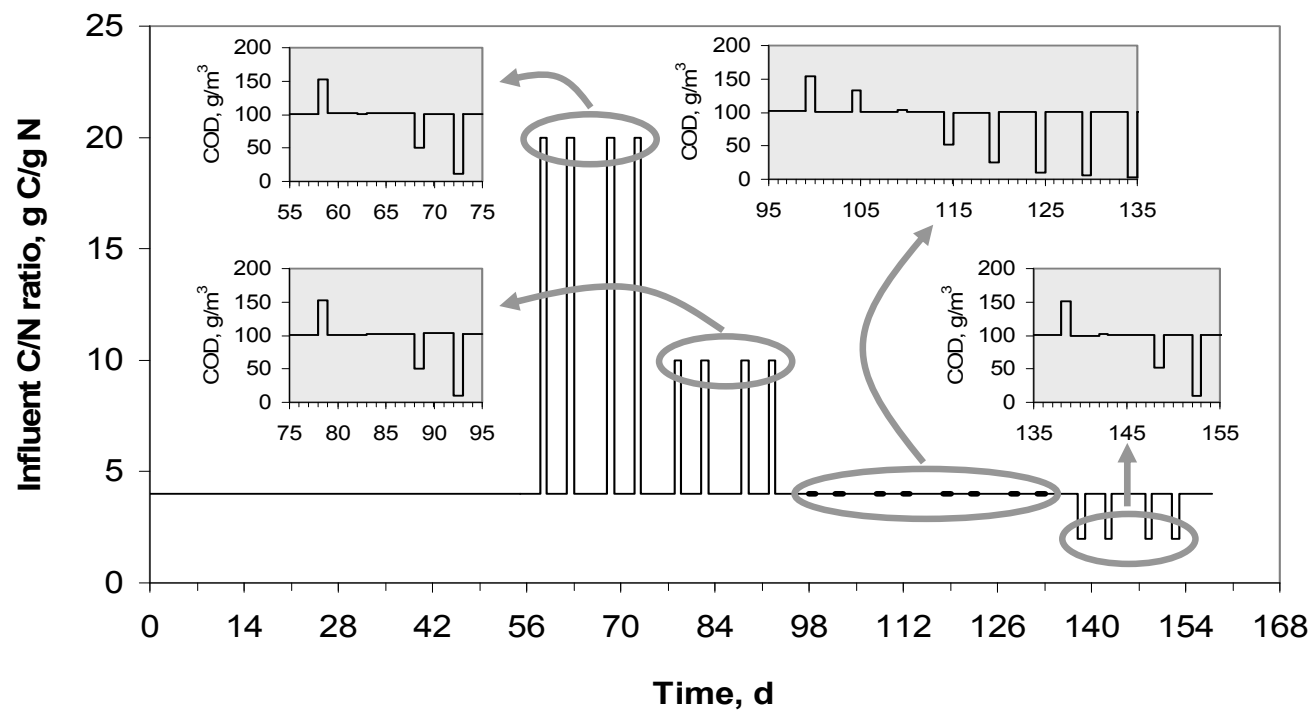

Figure 3 - Schematic illustration of the experimental set-up including the submerged BPB reactor)

The reactor was backwashed every 10 days after performing two assays. A return to the steady-state conditions was observed after 8 hours of the continuous operation. During the steady-state conditions, the measurements of $\mathrm{DO}, \mathrm{pH}$, temperature, TOC, $\mathrm{COD}$ and $\mathrm{NH}_{4}-\mathrm{N}$ were performed every 2 days in the influent, $\mathrm{P} 2$ and effluent. During each experimental assay, the measurements of $\mathrm{DO}, \mathrm{pH}$, temperature, TOC, $\mathrm{COD}, \mathrm{NH}_{4}-\mathrm{N}, \mathrm{NO}_{2}-\mathrm{N}, \mathrm{NO}_{3}-\mathrm{N}$ and alkalinity were performed three times, i.e. 12, 16 and $20 \mathrm{~h}$ after changing the operating conditions, in the influent, all the sampling ports and the effluent. In addition, during this phase (week 10, 15, 20 and 26), four grains of the media were collected in each of the five sampling ports in order to evaluate the biofilm thickness variations across the bed. The temperature in the BPB reactor was kept constant at approximately 20 ${ }^{\circ} \mathrm{C}$ during the entire experimental phase. 


\section{Analytical Methods}

The measurements of DO, $\mathrm{pH}$ and temperature were carried out with the $\mathrm{D} 201$ flow through vessel using probes SenTix 41 and CellOx 325 connected to the Multi 340i meter (WTW, Germany). Concentrations of organic carbon were measured as both Chemical Oxygen Demand (COD), by closed reflux digestion and titrimetric method (APHA-AWWA-WEF, 1999), and total organic carbon (TOC) using the TOC-5000 analyzer (Shimadzu, Japan). Concentrations of nitrogen compounds $\left(\mathrm{NH}_{4}-\mathrm{N}, \mathrm{NO}_{2}-\mathrm{N}, \mathrm{NO}_{3}-\mathrm{N}\right)$ were determined by spectrophotometry. The first two forms, i.e. $\mathrm{NH}_{4}-\mathrm{N}, \mathrm{NO}_{2}-\mathrm{N}$, were measured according to the Standard Methods (APHA-AWWA-WEF, 1999), whereas $\mathrm{NO}_{3}-\mathrm{N}$ concentrations were measured using the LCK 339 cuvette test $(0.23-13.5 \mathrm{~g}$ $\mathrm{NO}_{3}-\mathrm{N} / \mathrm{m}^{3}$ ) and the Cadas 50 spectrophotometer (HACH LANGE, Germany). Total and volatile suspended solids (TSS and VSS) concentrations were determined using $0.45 \mu \mathrm{m}$ pore size filters gravimetric method (APHA-AWWA-WEF, 1999). Alkalinity measurements were performed with the titration method (APHA-AWWA-WEF, 1999). The biofilm thickness was evaluated using an electronic microscope (Hitachi S 2700, Japan) after the sample (substratum/biofilm) dehydratation with acetone.

\section{Analysis of Elementary Mass Balances}

The experimental data collected during the long-term operation of the BPB reactor were used to calculate and analyze the elementary mass balances for $\mathrm{COD}, \mathrm{DO}, \mathrm{NH}_{4}-\mathrm{N}$ and alkalinity. The analysis was conducted according to a 5 -step procedure outlined by Tchobanoglous et al. (2003), which includes the definition of a flow diagram, control volume boundaries, pertinent data and assumptions, process rate expressions and basis for the numerical solutions.

A stoichiometric matrix used for calculations in this study is presented in Table 2. The matrix contains two processes (heterotrophic growth and nitrifier growth) and four components $\left(\mathrm{S}_{\mathrm{S}}, \mathrm{S}_{\mathrm{O}}\right.$, $\mathrm{S}_{\mathrm{NH}}, \mathrm{S}_{\mathrm{ALK}}$ ). The expressions for stoichiometric coefficients were set in accordance with the Activated Sludge Model no. 1 (ASM1) with a revision for readily biodegradable substrate (acetate) included in the Activated Sludge Model 2d (ASM2d) (Henze et al., 2000). For simplicity, the decay processes of heterotrophs and nitrifiers were not considered in the mass balance analysis.

Table 2 - Stoichiometric matrix of the processes related to the heterotrophic and nitrifier activity

\begin{tabular}{|l|l|l|c|c|}
\hline & \multicolumn{1}{|c|}{$\mathbf{S}_{\mathbf{S}}$} & \multicolumn{1}{c|}{$\mathbf{S}_{\mathbf{O}}$} & $\mathbf{S}_{\mathbf{N H}}$ & $\mathbf{S}_{\mathrm{ALK}}$ \\
\hline & $\mathbf{g ~ C O D} / \mathbf{m}^{\mathbf{3}}$ & $\mathbf{g ~ ( - C O D}) / \mathbf{m}^{\mathbf{3}}$ & $\mathbf{g ~ N} / \mathbf{m}^{\mathbf{3}}$ & $\mathbf{m o l e} / \mathbf{m}^{\mathbf{3}}$ \\
\hline $\begin{array}{l}\text { Heterotropic } \\
\text { activity }\end{array}$ & -1 & $-\left(1-\mathrm{Y}_{\mathrm{H}}\right)$ & $-\mathrm{i}_{\mathrm{N}, \mathrm{XB}} \cdot \mathrm{Y}_{\mathrm{H}}$ & $\left(\frac{1}{64}+\frac{1}{14} \cdot \mathrm{i}_{\mathrm{N}, \mathrm{XB}} \cdot \mathrm{Y}_{\mathrm{H}}\right)$ \\
\hline $\begin{array}{l}\text { Nitrifier } \\
\text { activity }\end{array}$ & & $-\left(4.57-\mathrm{Y}_{\mathrm{A}}\right)$ & $-\left(1+\mathrm{i}_{\mathrm{N}, \mathrm{XB}} \cdot \mathrm{Y}_{\mathrm{A}}\right)$ & $-\left(\frac{1}{7}+\frac{1}{14} \cdot \mathrm{i}_{\mathrm{N}, \mathrm{XB}} \cdot \mathrm{Y}_{\mathrm{A}}\right)$ \\
\hline
\end{tabular}

where: $\mathrm{i}_{\mathrm{N}, \mathrm{XB}}=0.086 \mathrm{~g} \mathrm{~N} / \mathrm{g}$ COD, $\mathrm{Y}_{\mathrm{A}}=0.24 \mathrm{~g} \mathrm{COD} / \mathrm{g} \mathrm{N}, \mathrm{Y}_{\mathrm{H}}=0.63 \mathrm{~g} \mathrm{COD} / \mathrm{g}$ COD (Henze et al., 2000)

The obtained calculation results were interpreted according to a flowchart presented in Figure 4. In the first step, the theoretical requirements for heterotrophic growth on acetate were calculated based on the observed amount of COD consumed $(\Delta C O D)$. When these requirements were satisfied, i.e. $\Delta \mathrm{DO}^{\prime} \geq 0$ and $\Delta \mathrm{NH}_{4}-\mathrm{N}^{\prime} \geq 0$, the theoretical requirements for nitrifier growth were calculated assuming 
the complete nitrification (one-step oxidation of $\mathrm{NH}_{4}-\mathrm{N}$ to $\mathrm{NO}_{3}-\mathrm{N}$ ). Finally, the limiting factor for nitrifier growth was determined based on the differences ( $\Delta \mathrm{DO}$ ' ' and $\Delta \mathrm{NH}_{4}-\mathrm{N}$ ') ) of the requirements and available amounts of the substrates. It should be noted that the decision of whether nitrification was possible or not in the theoretical calculations was based in some cases on the second digit after the decimal point. In practice, such low values are below the accuracy limit of measurement devices. Therefore, it was assumed in this study that nitrification could still be possible at a theoretical deficit of up to $-0.1 \mathrm{~g} \mathrm{~N} / \mathrm{m}^{3}$ for $\mathrm{NH}_{4}-\mathrm{N}$ or $-0.1 \mathrm{~g} \mathrm{COD} / \mathrm{m}^{3}$ for $\mathrm{DO}$. 


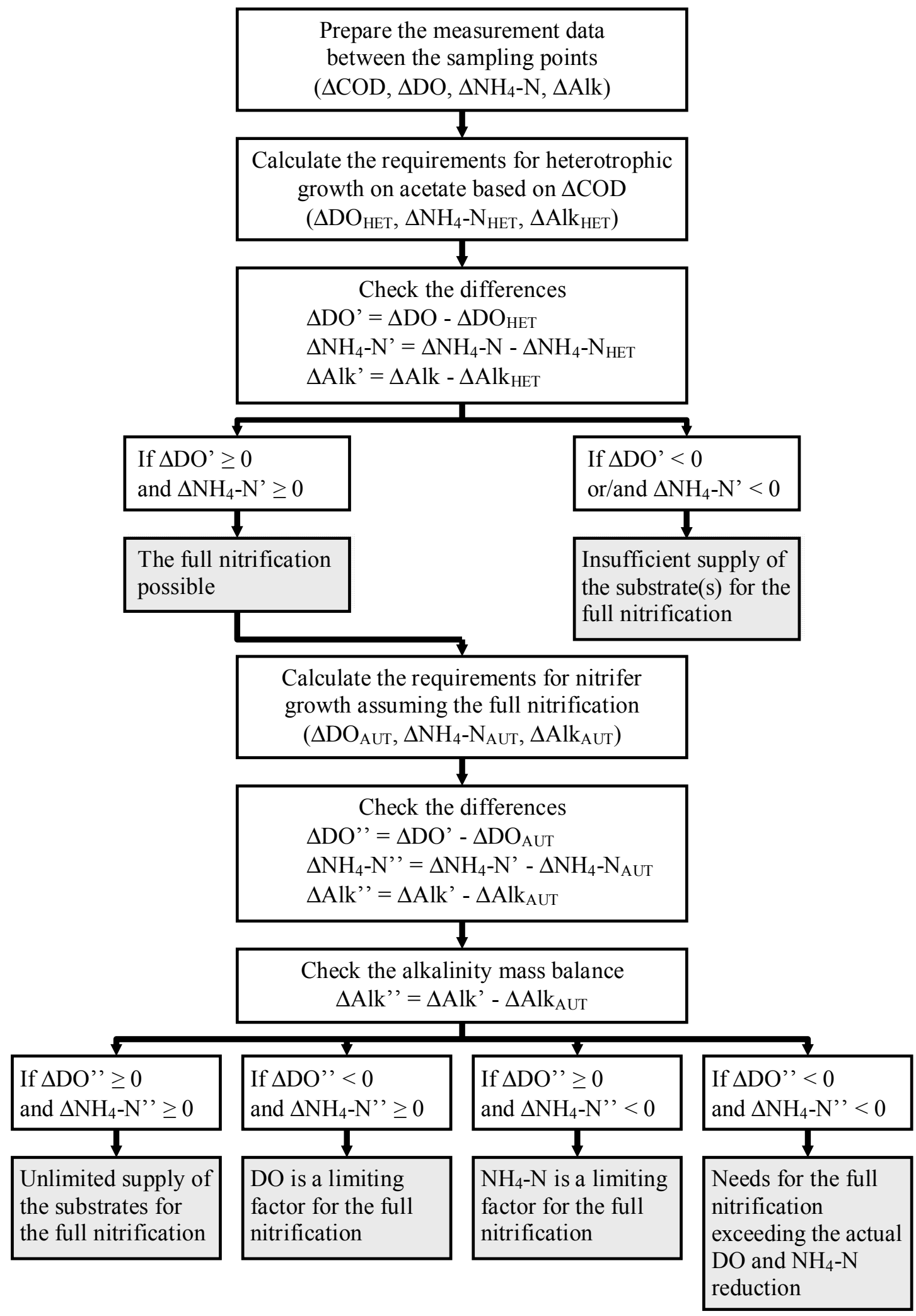

Figure 4 - Flowchart of a step-wise procedure for calculating the mass balances of substrate, DO, NH4-N and alkalinity 


\section{RESULTS}

\section{Performance of the BPB Reactor Under Steady State Conditions}

The steady-state conditions, in terms of the efficiency of COD and $\mathrm{NH}_{4}-\mathrm{N}$ removal, were attained in phase II after approximately 8 days of the continuous operation (Figure 5). The average COD concentrations (considering 14 samples and a 95\% confidence interval) were $102( \pm 0), 86( \pm 2)$ and $84( \pm 1) \mathrm{g} \mathrm{COD} / \mathrm{m}^{3}$, respectively, in the influent, $\mathrm{P} 2$ and the effluent. The average $\mathrm{NH}_{4}-\mathrm{N}$ concentrations in the same points were $10.3( \pm 0.2), 7.7( \pm 0.1)$ and $7.4( \pm 0.1) \mathrm{g} \mathrm{N} / \mathrm{m}^{3}$. As it can be seen, the operation of the BPB reactor was characterized by low relative removal efficiencies in terms of both $\mathrm{COD}(17.9 \%)$ and $\mathrm{NH}_{4}-\mathrm{N}(28.4 \%)$, and approximately $90 \%$ of the removal occurred in the upper section of the BPB reactor (TM-P2). The average DO concentrations were stable and equal to $7.5( \pm 0.1), 0.4( \pm 0.1)$ and $0.3( \pm 0.05) \mathrm{g} \mathrm{O}_{2} / \mathrm{m}^{3}$, respectively, in the influent, $\mathrm{P} 2$ and the effluent. The concentrations of TSS and VSS in P2 and in the effluent were $54( \pm 4)$ and $38( \pm 4) \mathrm{g} \mathrm{TSS} / \mathrm{m}^{3}$ and $28( \pm 3)$ and $16( \pm 2) \mathrm{g} \mathrm{VSS} / \mathrm{m}^{3}$, respectively, which corresponds a ratio VSS/TSS of 0.52 and 0.42 , respectively, in these two points.

After 10 days of the operation at steady-state conditions, the head losses in the first two sections (TM-P1 and P1-P2) increased quickly and diminished removal of COD and ammonia occurred due to clogging of the bed (data presented in Albuquerque (2003)). Based on this finding, backwashing was scheduled every 10 days during the continuous operation. After $6 \mathrm{~h}$ of backwashing, the COD removal efficiency reached $90 \%$ of that observed at steady state, and COD removal was fully recovered after another 2 hours. No negative effects due to backwashing on the removal of COD and ammonia were observed after that period (Albuquerque, 2003).
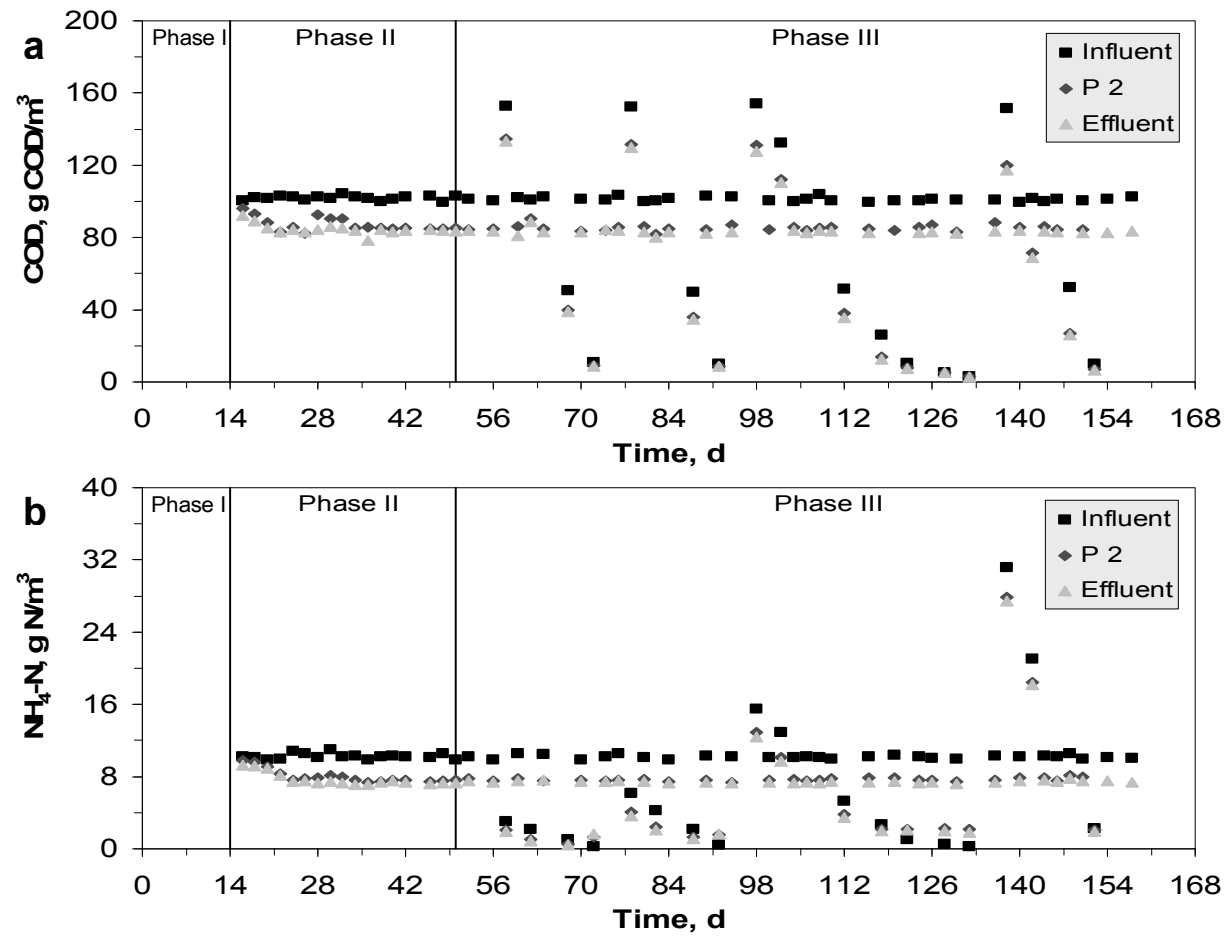

Figure 5 - COD and NH4-N concentrations in the selected points (influent, P2 and effluent) during the operation of the experimental set-up 


\section{Performance of the BPB Reactor During the Experimental Assays}

In phase III, the experimental assays performed at the different influent concentrations or $\mathrm{C} / \mathrm{N}$ ratios compared to the steady-state conditions (Figure 5). The effluent COD and ammonia concentrations changed with varying influent conditions. It was found, however, that the steady-state conditions returned in approximately 15 hours after each assay. Without considering the assays, the average COD concentrations in phase III were $101 \mathrm{~g} \mathrm{COD} / \mathrm{m}^{3}$ (influent), $85 \mathrm{~g} \mathrm{COD} / \mathrm{m}^{3}$ (P2) and $83 \mathrm{~g}$ $\mathrm{COD} / \mathrm{m}^{3}$ (effluent). The corresponding average $\mathrm{NH}_{4}-\mathrm{N}$ concentrations were: $10.2( \pm 0.08) \mathrm{g} \mathrm{N} / \mathrm{m}^{3}$ (influent), $7.65( \pm 0.07) \mathrm{g} \mathrm{N} / \mathrm{m}^{3}(\mathrm{P} 2)$ and $7.41( \pm 0.05) \mathrm{g} \mathrm{N} / \mathrm{m}^{3}$ (effluent). The average removal efficiencies were $16 \%$ and $25 \%$ for COD and $\mathrm{NH}_{4}-\mathrm{N}$. The average DO concentrations were 7.70 $( \pm 0.05), 0.50( \pm 0.05)$ and $0.40( \pm 0.04) \mathrm{g} \mathrm{O}_{2} / \mathrm{m}^{3}$ for same three measuring points. All these results remain very close to the observed concentrations in phase II under steady state conditions (see above).

Regardless of the applied $\mathrm{C} / \mathrm{N}$ ratio, there was no significant removal of $\mathrm{NH}_{4}-\mathrm{N}$ and $\mathrm{COD}$ in the assays with lowest influent COD concentrations from 3 to $11 \mathrm{~g} \mathrm{COD} / \mathrm{m}^{3}$ and lowest influent $\mathrm{NH}_{4}-\mathrm{N}$ concentrations from 0.2 to $2.2 \mathrm{~g} \mathrm{~N} / \mathrm{m}^{3}$ (assays A1.2.6., A2.2.6., A3.2.6., A3.2.7., A3.2.8. and A4.2.6.). The $\mathrm{DO}$ concentrations were higher than the ones observed under steady-state conditions or in the other assays, ranging from 3.2 to $4.5 \mathrm{O}_{2} / \mathrm{m}^{3}(\mathrm{P} 1), 2.5$ to $4.2 \mathrm{O}_{2} / \mathrm{m}^{3}(\mathrm{P} 2)$ and 2.1 to $4.0 \mathrm{O}_{2} / \mathrm{m}^{3}$ (P3 to effluent).

More detailed results of the remaining 14 experimental assays revealed that the removal of COD and $\mathrm{NH}_{4}-\mathrm{N}$ was only observed in the upper part (i.e. in section 1 and section 2). This is illustrated in Figure 6 showing the vertical profiles of biofilm thickness, $\mathrm{COD}, \mathrm{DO}$ and $\mathrm{NH}_{4}-\mathrm{N}$ for four selected assays. As it can be seen, the development of biofilm was explicitly associated with the availability of DO. The measured biofilm thickness in P1 and P2, during steady-state conditions was $0.72 \pm 0.10$ $\mathrm{mm}(\mathrm{P} 1)$ and $0.51 \pm 0.05 \mathrm{~mm}(\mathrm{P} 2)$, whereas the DO concentrations in these points, for experiments with COD concentrations over $10 \mathrm{~g} \mathrm{COD} / \mathrm{m}^{3}$, ranged from 0.8 to $1.9 \mathrm{~g} \mathrm{O}_{2} / \mathrm{m}^{3}$ (P1) and from 0.6 to $1.1 \mathrm{~g} \mathrm{O}_{2} / \mathrm{m}^{3}$ (P2). In the remaining points, the biofilm was relatively thin $(<0.10 \mathrm{~mm})$ and the DO concentrations ranged from 0.4 to $1 \mathrm{~g} \mathrm{O}_{2} / \mathrm{m}^{3}$ (P3 to effluent).

In section 1 of the reactor (TM-P1), the amounts of $\mathrm{NH}_{4}-\mathrm{N}$ and COD removed in the 14 experimental assays were strongly correlated $\left(\mathrm{r}^{2}=0.86\right)$ at the ratio of $0.094 \mathrm{~g} \mathrm{NH}_{4}-\mathrm{N} / \mathrm{g}$ COD. This value is very close to the ASM1 default value of the conversion factor indicating the content of nitrogen per COD biomass, $\mathrm{i}_{\mathrm{N}, \mathrm{XB}}=0.086 \mathrm{~g} \mathrm{~N} / \mathrm{g}$ COD (Henze et al., 2000). In section 2 of the reactor (P1-P2), the calculated value of the ratio was $0.169 \mathrm{~g} \mathrm{NH}_{4}-\mathrm{N} / \mathrm{g} \mathrm{COD}\left(\mathrm{r}^{2}=0.78\right)$ indicating that the amount of $\mathrm{NH}_{4}-\mathrm{N}$ removed exceeded the nitrogen requirements for biomass assimilation. It should be noted, however, that no $\mathrm{NH}_{4}-\mathrm{N}$ removal was observed in both sections in the experiments with the influent COD concentration below $10 \mathrm{~g} \mathrm{COD} / \mathrm{m}^{3}$. In these cases, the amounts of COD removed in section 1 and section 2 did not exceed 2.5 and $0.5 \mathrm{~g} \mathrm{COD} / \mathrm{m}^{3}$, respectively.

Both oxidized forms of nitrogen $\left(\mathrm{NO}_{2}-\mathrm{N}\right.$ and $\left.\mathrm{NO}_{3}-\mathrm{N}\right)$ were only detected in the upper part of the biofilm, but not in the all experimental assays. Very low concentrations of $\mathrm{NO}_{2}-\mathrm{N}(0.10-0.30 \mathrm{~g}$ $\mathrm{N} / \mathrm{m}^{3}$ ) were measured in $\mathrm{P} 2$ in only 7 assays, but none was found in $\mathrm{P} 1 . \mathrm{NO}_{3}-\mathrm{N}$ appeared in 15 assays and the concentration was up to 2.05 and to $2.15 \mathrm{~g} \mathrm{~N} / \mathrm{m}^{3}$, in section 1 (TM-P1) and section 2 (P1-P2), respectively. Despite the different $\mathrm{C} / \mathrm{N}$ ratios utilized in the assays, a strong linear relationship $\left(\mathrm{r}^{2}=0.86\right)$ was found in section $1(\mathrm{TM}-\mathrm{P} 1)$ between the amount of $\mathrm{NH}_{4}-\mathrm{N}$ utilized and $\mathrm{NO}_{3}-\mathrm{N}$ produced $\left(=0.79 \mathrm{~g} \mathrm{NO}_{3}-\mathrm{N} / \mathrm{g} \mathrm{NH}_{4}-\mathrm{N}\right)$ while considering all the 20 experiments. For the assays with the ratio $\mathrm{C} / \mathrm{N}=2,4$ and 10 , the correlations were higher than the average value, and the 
calculated $\mathrm{r}^{2}$ coefficients were $0.96,0.93$ and 0.97 , respectively. In section 2 , the concentrations of $\mathrm{NO}_{3}-\mathrm{N}$ increased only slightly or even dropped in comparison with section 1. Occasionally (7 assays), low $\mathrm{NO}_{3}-\mathrm{N}$ concentrations (up to $0.53 \mathrm{~g} \mathrm{~N} / \mathrm{m}^{3}$ ) were also detected in $\mathrm{P} 3$.
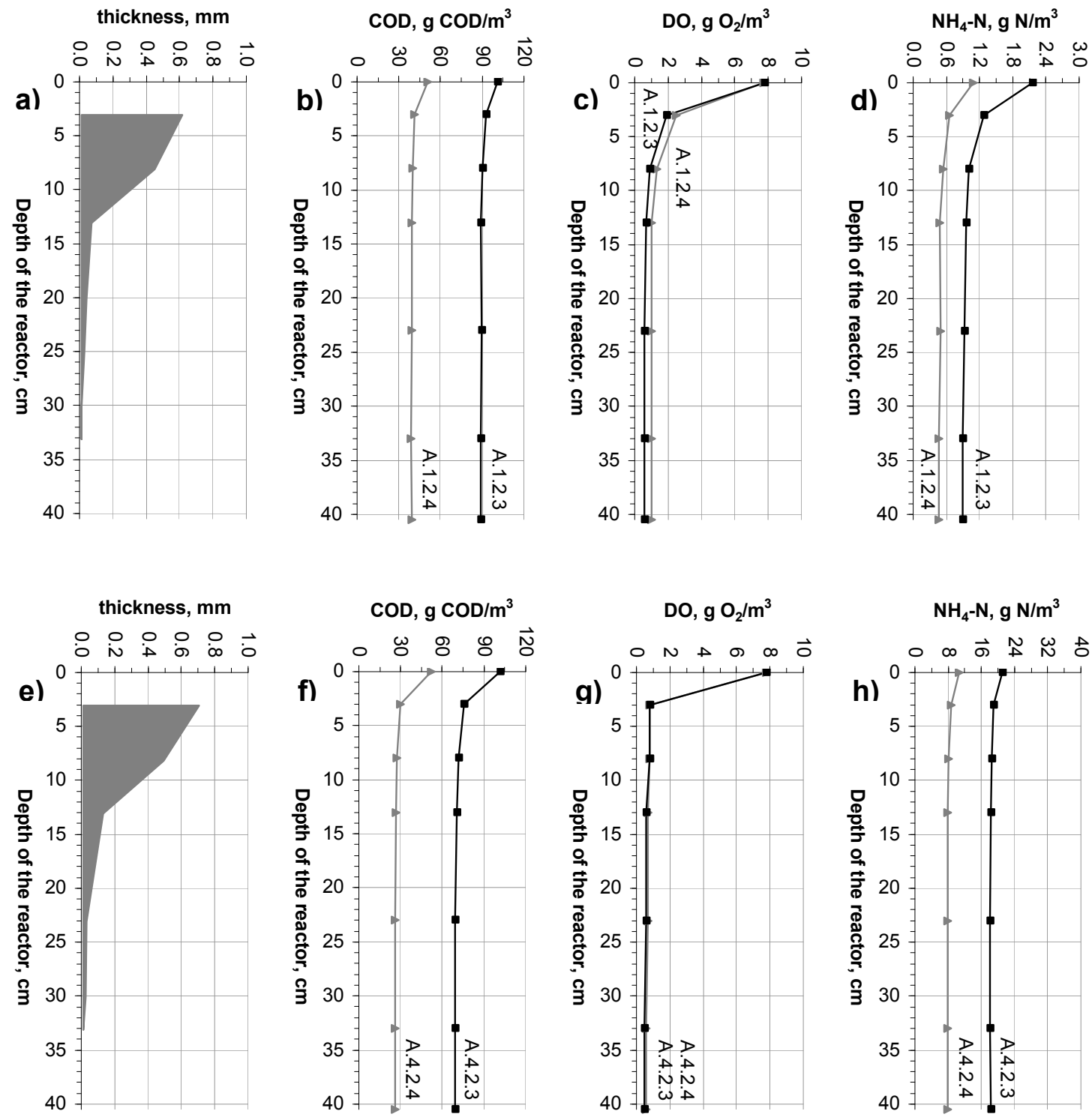

Figure 6 - Vertical profiles of COD, DO and $\mathrm{NH}_{4}-\mathrm{N}$ concentrations and biofilm thickness during the selected experimental assays (a-d - assays 1.2.3-1.2.4, e-h - assays 4.2.3-4.2.4)

\section{Mass Balance Calculations}

Using the stoichiometric matrix (Table 2$)$ and measured consumptions of substrate $\left(\mathrm{S}_{\mathrm{S}}\right), \mathrm{DO}\left(\mathrm{S}_{\mathrm{O}}\right)$ and $\mathrm{NH}_{4}-\mathrm{N}\left(\mathrm{S}_{\mathrm{NH}}\right)$ in sections 1 and 2, the elementary mass balances of those components were calculated according to the flow chart presented in Figure 4. In addition, the mass balances for alkalinity were also considered. The results of these calculations are listed in Table 3 (section 1) and Table 4 (section 2). 
Table 3. Results of the mass balance calculations for section 1 (influent - sampling point 1)

\begin{tabular}{|c|c|c|c|c|c|c|c|c|c|c|c|c|c|c|c|c|c|c|c|c|}
\hline \multirow{12}{*}{ 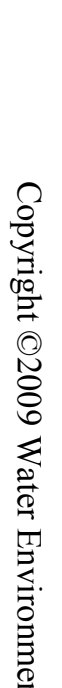 } & \multirow[b]{3}{*}{ 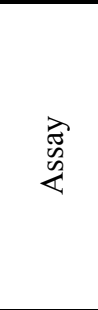 } & \multirow[b]{3}{*}{ 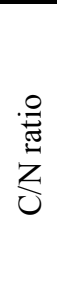 } & \multicolumn{4}{|c|}{$\begin{array}{l}\text { Measured consumption } \\
\text { (experimental data) }\end{array}$} & \multicolumn{3}{|c|}{$\begin{array}{l}\text { Requirement } \\
\text { (heterotrophic) }\end{array}$} & \multicolumn{3}{|c|}{ Deficit/surplus } & \multirow{3}{*}{ 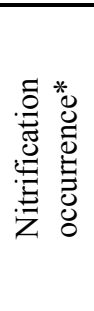 } & \multirow{3}{*}{ 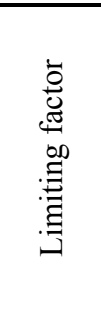 } & \multicolumn{3}{|c|}{$\begin{array}{l}\text { Requirement } \\
\text { (autotrophic) }\end{array}$} & \multicolumn{3}{|c|}{ Total deficit/surplus } \\
\hline & & & $\mathrm{S}_{\mathrm{S}}$ & $\mathrm{S}_{\mathrm{O}}$ & $\mathrm{S}_{\mathrm{NH}}$ & $\mathrm{S}_{\mathrm{ALK}}$ & $\mathrm{S}_{\mathrm{O}}$ & $\mathrm{S}_{\mathrm{NH}}$ & $\mathrm{S}_{\mathrm{ALK}}$ & $\mathrm{S}_{\mathrm{O}}$ & $\mathrm{S}_{\mathrm{NH}}$ & $\mathrm{S}_{\mathrm{ALK}}$ & & & $\mathrm{S}_{\mathrm{O}}$ & $\mathrm{S}_{\mathrm{NH}}$ & $\mathrm{S}_{\mathrm{ALK}}$ & $\mathrm{S}_{\mathrm{O}}$ & $\mathrm{S}_{\mathrm{NH}}$ & $\mathrm{S}_{\mathrm{ALK}}$ \\
\hline & & & $\overbrace{0}^{3}$ & 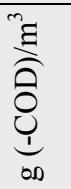 & $\stackrel{m}{Z}_{\infty}^{m}$ & $\overbrace{\infty}^{n}$ & 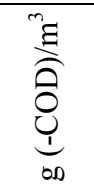 & $\stackrel{\text { Z }}{Z}_{Z_{0}}^{E}$ & $\underbrace{\tilde{E}}_{\infty}$ & $\underbrace{\stackrel{n}{\Xi}}_{\infty}$ & $\stackrel{m}{Z}_{\infty}^{\Xi}$ & $\underbrace{m}_{\infty}$ & & & 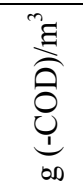 & $\sum_{\infty}^{m}$ & $\underbrace{\overbrace{0}^{\infty}}_{\infty}$ & 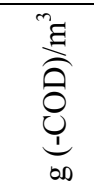 & $\sum_{\infty}^{\infty}$ & $\underbrace{j}_{\infty}$ \\
\hline & 1.2 .6 . & & 1.3 & 3.8 & 0.00 & -1.1 & 0.48 & 0.07 & -2.53 & 3.32 & -0.07 & 1.43 & $\mathrm{P}$ & & & & & 3.32 & -0.07 & 1.43 \\
\hline & 1.2.4. & & 9.5 & 5.2 & 0.42 & -11.0 & 3.52 & 0.51 & -18.52 & 1.68 & -0.09 & 7.52 & $\mathrm{P}$ & & & & & 1.68 & -0.09 & 7.52 \\
\hline & 1.2.3. & 20 & 7.9 & 5.9 & 0.88 & -11.0 & 2.92 & 0.43 & -15.40 & 2.98 & 0.45 & 4.40 & $\mathrm{Y}$ & $\mathrm{NH}_{4}-\mathrm{N}$ & 1.95 & 0.45 & 6.49 & 1.03 & 0 & -2.09 \\
\hline & 1.2 .1$. & & 16.0 & 5.9 & 0.73 & -11.1 & 5.92 & 0.87 & -31.19 & -0.02 & -0.14 & 20.09 & $\mathrm{P}$ & & & & & -0.02 & -0.14 & 20.09 \\
\hline & 2.2 .6 & & 1.0 & 4.5 & 0.00 & -1.0 & 0.37 & 0.05 & -1.95 & 4.13 & -0.05 & 0.95 & $\mathrm{P}$ & & & & & 4.13 & -0.05 & 0.95 \\
\hline & 2.2 .4 & & 11.2 & 6.6 & 0.62 & -8.9 & 4.14 & 0.61 & -21.83 & 2.46 & 0.01 & 12.93 & Y & $\mathrm{NH}_{4}-\mathrm{N}$ & 0.04 & 0.01 & 0.14 & 2.42 & 0 & 12.79 \\
\hline & 2.2.3. & 10 & 15.6 & 5.9 & 1.32 & -10.1 & 5.77 & 0.85 & -30.41 & 0.13 & 0.47 & 20.31 & Y & DO & 0.13 & 0.03 & 0.43 & 0 & 0.44 & 19.88 \\
\hline & 2.2 .1 & & 16.7 & 6.3 & 1.40 & -14.3 & 6.18 & 0.90 & -32.56 & 0.12 & 0.50 & 18.26 & Y & DO & 0.12 & 0.03 & 0.43 & 0 & 0.47 & 17.83 \\
\hline & 3.2 .8 & & 0.0 & 3.3 & 0.00 & 0.0 & 0.00 & 0.00 & 0.00 & 3.30 & 0.00 & 0.00 & $\mathrm{P}$ & & & & & 3.3 & 0 & 0 \\
\hline$\stackrel{\overrightarrow{7}}{\mathrm{~T}}$ & 3.2 .7 & & 0.1 & 3.6 & 0.00 & -0.3 & 0.04 & 0.01 & -0.19 & 3.56 & -0.01 & -0.11 & $\mathrm{P}$ & & & & & 3.56 & -0.01 & -0.11 \\
\hline 8 & 3.2 .6 . & & 2.1 & 3.8 & 0.00 & -2.1 & 0.78 & 0.11 & -4.09 & 3.02 & -0.11 & 1.99 & $\mathrm{~N}$ & & & & & 3.02 & -0.11 & 1.99 \\
\hline$\stackrel{9}{\stackrel{9}{\sharp}}$ & 3.2 .5 . & & 10.2 & 6.6 & 0.31 & -5.7 & 3.77 & 0.55 & -19.88 & 2.83 & -0.24 & 14.18 & $\mathrm{~N}$ & & & & & 2.83 & -0.24 & 14.18 \\
\hline $\overrightarrow{0}$ & 3.2.4. & & 11.5 & 6.8 & 1.06 & -9.2 & 4.26 & 0.62 & -22.42 & 2.54 & 0.44 & 13.22 & $\mathrm{Y}$ & NH4-N & 1.91 & 0.44 & 6.35 & 0.63 & 0 & 6.87 \\
\hline$P$ & 3.2.3. & 4 & 15.7 & 6.3 & 1.95 & -10.9 & 5.81 & 0.85 & -30.61 & 0.49 & 1.10 & 19.71 & $\mathrm{Y}$ & DO & 0.49 & 0.11 & 1.59 & 0 & 0.99 & 18.12 \\
\hline $\bar{T}$ & 3.2 .2 & & 17.4 & 6.4 & 2.15 & -11.3 & 6.44 & 0.94 & -33.92 & -0.04 & 1.21 & 22.62 & $\mathrm{P}$ & & & & & -0.04 & 1.21 & 22.62 \\
\hline 중. & 3.2 .1 . & & 18.7 & 6.7 & 2.04 & -17.2 & 6.92 & 1.01 & -36.46 & -0.22 & 1.03 & 19.26 & $\mathrm{~N}$ & & & & & -0.22 & 1.03 & 19.26 \\
\hline$\vec{F}$ & 4.2 .6$. & & 2.7 & 5.1 & 0.11 & -2.3 & 1.00 & 0.15 & -5.26 & 4.10 & -0.04 & 2.96 & $\mathrm{P}$ & & & & & 4.1 & -0.04 & 2.96 \\
\hline$\ddot{0}$ & 4.2.4. & & 22.5 & 7.0 & 1.97 & -9.7 & 8.33 & 1.22 & -43.86 & -1.33 & 0.75 & 34.16 & $\mathrm{~N}$ & & & & & -1.33 & 0.75 & 34.16 \\
\hline$\stackrel{\infty}{\Omega}$ & 4.2.3. & 2 & 26.3 & 7.0 & 2.16 & -12.6 & 9.73 & 1.42 & -51.27 & -2.73 & 0.74 & 38.67 & $\mathrm{~N}$ & & & & & -2.73 & 0.74 & 38.67 \\
\hline ฉ & 4.2.1. & & 28.1 & 7.0 & 2.44 & -15.8 & 10.40 & 1.52 & -54.78 & -3.40 & 0.92 & 38.98 & $\mathrm{~N}$ & & & & & -3.4 & 0.92 & 38.98 \\
\hline
\end{tabular}

${ }^{*} \mathrm{Y}-$ yes, $\mathrm{N}-$ no, $\mathrm{P}$ - posible 
Table 4. Results of the mass balance calculations for section 2 (sampling point 1 - sampling point 2)

\begin{tabular}{|c|c|c|c|c|c|c|c|c|c|c|c|c|c|c|c|c|c|c|c|c|}
\hline \multirow{11}{*}{ 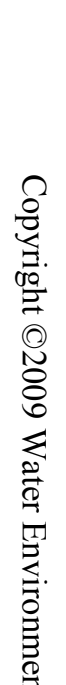 } & \multirow[b]{3}{*}{$\begin{array}{l}\text { 吾 } \\
\text { 玄 }\end{array}$} & \multirow{3}{*}{ 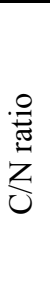 } & \multicolumn{4}{|c|}{$\begin{array}{l}\text { Measured consumption } \\
\text { (experimental data) }\end{array}$} & \multicolumn{3}{|c|}{$\begin{array}{c}\text { Requirement } \\
\text { (heterotrophic) }\end{array}$} & \multicolumn{3}{|c|}{ Deficit/surplus } & \multirow{3}{*}{ 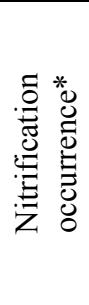 } & \multirow{3}{*}{ 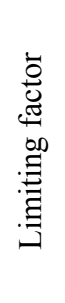 } & \multicolumn{3}{|c|}{$\begin{array}{l}\text { Requirement } \\
\text { (autotrophic) }\end{array}$} & \multicolumn{3}{|c|}{ Total deficit/surplus } \\
\hline & & & $\mathrm{S}_{\mathrm{S}}$ & $\mathrm{S}_{\mathrm{O}}$ & $\mathrm{S}_{\mathrm{NH}}$ & $\mathrm{S}_{\mathrm{ALK}}$ & $\mathrm{S}_{\mathrm{O}}$ & $\mathrm{S}_{\mathrm{NH}}$ & $\mathrm{S}_{\mathrm{ALK}}$ & $\mathrm{S}_{\mathrm{O}}$ & $\mathrm{S}_{\mathrm{NH}}$ & $\mathrm{S}_{\mathrm{ALK}}$ & & & $\mathrm{S}_{\mathrm{O}}$ & $\mathrm{S}_{\mathrm{NH}}$ & $\mathrm{S}_{\mathrm{ALK}}$ & $\mathrm{S}_{\mathrm{O}}$ & $\mathrm{S}_{\mathrm{NH}}$ & $\mathrm{S}_{\mathrm{ALK}}$ \\
\hline & & & 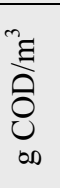 & 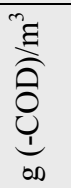 & $\underbrace{\text { Z }}_{\infty}$ & $\underbrace{n}_{0} \underbrace{\infty}_{0}$ & 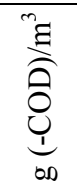 & $\underbrace{m}_{0 \infty}$ & $\underbrace{n}_{\infty}$ & 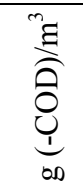 & $\sum_{\infty}^{m}$ & $\underbrace{\infty}_{\infty}$ & & & 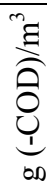 & $\underbrace{m}_{\infty}$ & $\overbrace{\infty}^{n}$ & 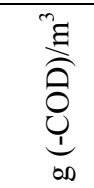 & $\underbrace{m}_{\infty}$ & $\underbrace{n}_{\infty}$ \\
\hline & 1.2 .6 . & \multirow{3}{*}{20} & 0.4 & 0.2 & 0.00 & -0.5 & 0.15 & 0.02 & -0.78 & 0.05 & -0.02 & 0.28 & $\mathrm{P}$ & & & & & 0.05 & -0.02 & 0.28 \\
\hline & 1.2.3. & & 2.7 & 1.3 & 0.24 & -7.5 & 1.00 & 0.15 & -5.26 & 0.30 & 0.09 & -2.24 & $\mathrm{~N}$ & & & & & 0.3 & 0.09 & -2.24 \\
\hline & 1.2.1. & & 2.1 & 1.2 & 0.21 & -9.5 & 0.78 & 0.11 & -4.09 & 0.42 & 0.10 & -5.41 & $\mathrm{~N}$ & & & & & 0.42 & 0.1 & -5.41 \\
\hline & 2.2 .6 & \multirow{4}{*}{10} & 0.3 & 0.5 & 0.00 & -0.7 & 0.11 & 0.02 & -0.58 & 0.39 & -0.02 & -0.12 & $\mathrm{P}$ & & & & & 0.39 & -0.02 & -0.12 \\
\hline & 2.2 .4 & & 2.7 & 0.1 & 0.26 & -7.8 & 1.00 & 0.15 & -5.26 & -0.90 & 0.11 & -2.54 & $\mathrm{~N}$ & & & & & -0.9 & 0.11 & -2.54 \\
\hline & 2.2.3. & & 2.9 & 1.0 & 0.49 & -10.0 & 1.07 & 0.16 & -5.65 & -0.07 & 0.33 & -4.35 & $\mathrm{P}$ & & & & & -0.07 & 0.33 & -4.35 \\
\hline & 2.2.1. & & 4.1 & 1.0 & 0.68 & -9.6 & 1.52 & 0.22 & -7.99 & -0.52 & 0.46 & -1.61 & $\mathrm{~N}$ & & & & & -0.52 & 0.46 & -1.61 \\
\hline & 3.2 .8 & \multirow{7}{*}{4} & 0.2 & 0.3 & 0.00 & -1.3 & 0.07 & 0.01 & -0.39 & 0.23 & -0.01 & -0.91 & $\mathrm{P}$ & & & & & 0.23 & -0.01 & -0.91 \\
\hline$\stackrel{8}{8}$ & 3.2 .6 . & & 0.3 & 1.5 & 0.00 & -0.6 & 0.11 & 0.02 & -0.58 & 1.39 & -0.02 & -0.02 & $\mathrm{P}$ & & & & & 1.39 & -0.02 & -0.02 \\
\hline$\stackrel{9}{0}$ & 3.2 .5 & & 1.8 & 0.3 & 0.18 & -5.2 & 0.67 & 0.10 & -3.51 & -0.37 & 0.08 & -1.69 & $\mathrm{~N}$ & & & & & -0.37 & 0.08 & -1.69 \\
\hline 뭉. & 3.2 .4 & & 1.8 & 0.2 & 0.38 & -7.4 & 0.67 & 0.10 & -3.51 & -0.47 & 0.28 & -3.89 & $\mathrm{~N}$ & & & & & -0.47 & 0.28 & -3.89 \\
\hline \multirow{7}{*}{ 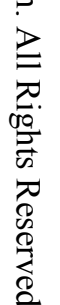 } & 3.2.3. & & 2.8 & 0.6 & 0.57 & -10.8 & 1.04 & 0.15 & -5.46 & -0.44 & 0.42 & -5.34 & $\mathrm{~N}$ & & & & & -0.44 & 0.42 & -5.34 \\
\hline & 3.2 .2 . & & 2.6 & 0.7 & 0.60 & -9.3 & 0.96 & 0.14 & -5.07 & -0.26 & 0.46 & -4.23 & $\mathrm{~N}$ & & & & & -0.26 & 0.46 & -4.23 \\
\hline & 3.2.1. & & 4.3 & 0.3 & 0.57 & -8.0 & 1.59 & 0.23 & -8.38 & -1.29 & 0.34 & 0.38 & $\mathrm{~N}$ & & & & & -1.29 & 0.34 & 0.38 \\
\hline & 4.2 .6 & & 0.3 & 0.0 & 0.00 & -0.5 & 0.11 & 0.02 & -0.58 & -0.11 & -0.02 & 0.08 & $\mathrm{~N}$ & & & & & -0.11 & -0.02 & 0.08 \\
\hline & 4.2 .4 & & 2.8 & 0.0 & 0.51 & -7.6 & 1.04 & 0.15 & -5.46 & -1.04 & 0.36 & -2.14 & $\mathrm{~N}$ & & & & & -1.04 & 0.36 & -2.14 \\
\hline & 4.2.3. & 2 & 3.8 & 0.0 & 0.45 & -9.2 & 1.41 & 0.21 & -7.41 & -1.41 & 0.24 & -1.79 & $\mathrm{~N}$ & & & & & -1.41 & 0.24 & -1.79 \\
\hline & 4.2.1. & & 3.1 & 0.2 & 0.81 & -9.1 & 1.15 & 0.17 & -6.04 & -0.95 & 0.64 & -3.06 & $\mathrm{~N}$ & & & & & -0.95 & 0.64 & -3.06 \\
\hline
\end{tabular}

${ }^{*} \mathrm{Y}-$ yes, $\mathrm{N}-$ no, $\mathrm{P}$ - possible 
The elementary mass balances could not explain all the experimental results. In section 2, most of the mass balance calculations, excluding the possibility of nitrification, were in general in accordance with the observations indicating no or minimal $\mathrm{NO}_{3}-\mathrm{N}$ production (see above). In section 1 , the theoretical requirements for nitrification were only satisfied in 6 assays (plus 8 "possible" cases) compared to the measurement results revealing $\mathrm{NO}_{3}-\mathrm{N}$ production in 15 assays. Only at the ratio $\mathrm{C} / \mathrm{N}=10$, the predictions confirmed the possibility of nitrification in the same 3 (out of 4 ) assays as observed in practice. It should be noted that the inconsistency between the theoretical calculations and measurements occurred at the highest ratio $\mathrm{C} / \mathrm{N}=20$ and low $\mathrm{C} / \mathrm{N}$ ratios $(=2$ and 4$)$ with high consumptions of the substrate, i.e. $22-28 \mathrm{~g} \mathrm{COD} / \mathrm{m}^{3}$ for $\mathrm{C} / \mathrm{N}=2$ and $17-19 \mathrm{~g} \mathrm{COD} / \mathrm{m}^{3}$ for

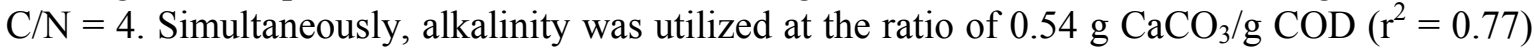
which is in accordance with the effect of acetate utilization but in contrast with the need for nitrification. The limitation of DO appeared to be a critical factor in section 1 and the production of $\mathrm{NO}_{3}-\mathrm{N}$ may indicate a successful competition of nitrifiers for $\mathrm{DO}$, which in contrast to the traditional hypothesis that nitrifiers are outcompeted by heterotrophs for DO. Moreover, the lack of nitrification predicted at the ratio $\mathrm{C} / \mathrm{N}=20$ remains in accordance with the simulation results of Wanner et al. (2006). The authors examined four different biofilm models of interaction between aerobic heterotrophs and nitrifiers, and concluded that net synthesis of heterotrophic biomass consumes most of the $\mathrm{NH}_{4}-\mathrm{N}$, eliminating nitrification and nitrifiers in the considered situation.

\section{DISCUSSION}

The results of this study reveal that the nitrogen transformations occurring in the aerobic BPB reactor are complex and cannot be explained by simple mechanisms of microbial assimilation and nitrification. The aim of this section is to give insight into alternate metabolic pathways leading to nitrogen removal in biofilm systems, but without providing the ultimate judgment with regard to the studied BPB. In literature, several new pathways have been reported (e.g. Schmidt et al., 2003; Khin and Annachhatre, 2004; Ahn, 2006; Paredes et al., 2007). Table 5 summarizes the characteristics of possible processes occurring in such systems and their effects on the mass balance calculations. Paredes et al. (2007) pointed out that attached biomass growth occurs in "mosaic macro- and microgradient systems". Khin and Annachhatre (2004) demonstrated that metabolic pathways for the conventional nitrification-denitrification and ANNAMOX are complex and may consist of 8 and 5 steps (reactions), respectively.

In biofilm systems, low DO concentrations usually lead to a stable, up to $100 \% \mathrm{NO}_{2}-\mathrm{N}$ accumulation (Paredes et al., 2007). Furthermore, the authors hypothesized based on a literature review that $\mathrm{NO}_{2}-$ $\mathrm{N}$ oxidizers are more exposed to oxygen limiting conditions than $\mathrm{NH}_{4}-\mathrm{N}$ oxidizers. This may be due to a higher oxygen saturation constant and/or specific spatial distribution of microorganisms, i.e. $\mathrm{NH}_{4}-\mathrm{N}$ oxidizers are located outside the biofilm, whereas $\mathrm{NO}_{2}-\mathrm{N}$ oxidizers are found in the deeper layer of the biofilm. This is in contradiction to a general opinion that the faster growing heterotrophs tend to dominate the outer part of a biofilm, while nitrifiers occur along with inerts closer to the substratum (Wanner et al., 2006).

Khin and Annachhatre (2004) pointed out that under DO limited conditions ( $<0.5 \%$ air saturation) a co-culture of aerobic and anaerobic $\mathrm{NH}_{4}-\mathrm{N}$ oxidizing (ANAMMOX) bacteria can be established, and this system is responsible for the process termed CANON, OLAND or aerobic deammonification (Table 6). The interaction of aerobic and anaerobic $\mathrm{NH}_{4}-\mathrm{N}$ oxidizing bacteria under DO limited conditions results in almost complete conversion of $\mathrm{NH}_{4}-\mathrm{N}$ to $\mathrm{N}_{2}$ gas, whereas only small amounts of $\mathrm{NO}_{3}-\mathrm{N}$ are produced. It should be noted that the ANAMMOX bacteria are very sensitive to DO and the concentrations higher than $0.06 \mathrm{~g} \mathrm{O}_{2} / \mathrm{m}^{3}$ were found to inhibit the ANAMMOX activity completely 
but reversibly (Paredes et al., 2007). This is another unfavorable factor for the growth of these bacteria, in addition to a very low maximum growth rate constant, $\mu_{\mathrm{AN}}=0.072 \mathrm{~d}^{-1}$ at $30^{\circ} \mathrm{C}$ (Jetten et al., 1998).

Yu et al. (2007) observed in full-scale drinking water biofilters that the actual $\mathrm{NO}_{3}-\mathrm{N}$ production and DO consumption were substantially lower compared to the theoretical stoichiometric requirements ("the nitrogen loss and DO paradox"). The authors hypothesized that this inconsistency may be attributed to alternate, non-nitrifying pathways. In contrast to the initial assumptions, assimilation and conventional denitrification were excluded as possible mechanisms based on the lack of correlation between the nitrogen loss and utilization of phosphate (as a microbial nutrient) and COD removal, respectively. The "aerobic deammonification" was identified as the most probable mechanisms that could well explain the nitrogen loss and DO paradox. According to this mechanism, approximately $57 \%$ of the removed $\mathrm{NH}_{4}-\mathrm{N}$ was associated with the complete nitrification, whereas approximately $21 \%$ of the removed $\mathrm{NH}_{4}-\mathrm{N}$ was incompletely oxidized to $\mathrm{NO}_{2}-$ $\mathrm{N}$. The latter served then as an electron acceptor in the ANAMMOX process with the remaining $\mathrm{NH}_{4}-\mathrm{N}$ removed (approximately 21\%) acting as the electron donor. However, the authors did not consider aerobic denitrification (Table 6) and assumed that "most of the removed COD was not oxidized by nitrate, but aerobically degraded".

In theory, also a combination of anaerobic $\mathrm{NH}_{4}-\mathrm{N}$ oxidation and denitrification can easily be obtained in biofilm systems at low oxygen concentrations (Paredes et al., 2007). In contrast to conventional denitrification processes, where the organic carbon could become a limiting factor because the electron donor for denitrification is more rapidly oxidized than $\mathrm{NH}_{4}-\mathrm{N}$. This problem does not exist in systems (CANON, OLAND and aerobic deammonification) with $\mathrm{NH}_{4}-\mathrm{N}$ as the electron donor. The authors also pointed out that the ANAMMOX bacteria are also very sensitive to the presence of some organic carbon sources, such as alcohols, especially methanol. On the other hand, volatile fatty acids (VFA) including propionate and potentially acetate were demonstrated to be converted by the ANAMMOX bacteria. Propionate was oxidized by the ANAMOX bacteria with nitrate and/or nitrite as the electron acceptor in parallel to anaerobic oxidation of $\mathrm{NH}_{4}-\mathrm{N}$. In an ANAMMOX enriched culture cultivated with propionate for long term, the amount of ANAMMOX cells and denitrifiers did not change significantly over time. Therefore, the authors concluded that the ANAMMOX bacteria could compete successfully with the heterotrophic denitrifiers for the VFA.

Ahn (2006) discussed two other mechanisms, including aerobic denitrification and autotrophic denitrification (Table 6), that contributed to nitrogen loss in the studied systems. In the first case, Pseudomonas bacteria isolated from the activated sludge of a sequencing batch reactor treating piggery wastewater were capable of rapidly reducing $\mathrm{NO}_{3}-\mathrm{N}$ to $\mathrm{N}_{2}$ gas without $\mathrm{NO}_{2}-\mathrm{N}$ accumulation under aerobic conditions. In the second case, Nitrosomonas-like microorganisms were found to nitrify and denitrify (using $\mathrm{H}^{+}$as the electron donor and $\mathrm{NO}_{2}-\mathrm{N}$ as the electron acceptor) simultaneously even under fully oxic or anoxic conditions with $\mathrm{N}_{2}$ gas as the main final product.

Other possible pathways for ammonia loss from the BPB that do not lead to nitrate or $\mathrm{N}_{2}$ could be due to short-circuiting of nitrification and denitrification pathways into gas phase $\mathrm{NO}$ and $\mathrm{N}_{2} \mathrm{O}$ through nitrite reduction (see the reactions below) (Colliver and Stephenson, 2000). Although, the mechanisms of these pathways are still under investigation and should be carefully considered in future research of BPB reactors under DO limiting conditions.

$\mathrm{NO}_{2}^{-}+2 \mathrm{H}^{+}+\mathrm{e}^{-} \longrightarrow \mathrm{NO}+\mathrm{H}_{2} \mathrm{O}$
$\mathrm{NO}+\mathrm{H}^{+}+\mathrm{e}^{-} \longrightarrow \frac{1}{2} \mathrm{~N}_{2} \mathrm{O}+\frac{1}{2} \mathrm{H}_{2} \mathrm{O}$

Copyright $@ 2009$ Water Environment Federation. All Rights Reserved. 
Table 5 - Effects of the newly discovered and considered nitrogen removal processes on the mass balance calculations (Schmidt $e$ t al., 2003; Ahn, 2006; Paredes et al., 2007)

\begin{tabular}{|c|c|c|c|c|c|c|}
\hline \multirow{8}{*}{ 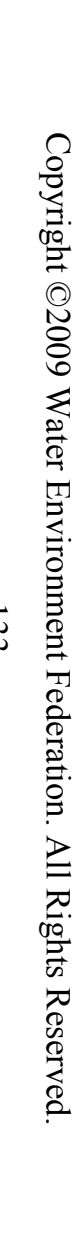 } & Process & $\begin{array}{c}\mathrm{N} \\
\text { substrates }\end{array}$ & $\begin{array}{l}\text { Requirements } \\
\text { DO }\end{array}$ & Organic carbon & Alkalinity & $\begin{array}{c}\mathrm{N} \\
\text { products }\end{array}$ \\
\hline & Full (one-step) nitrification & $\mathrm{NH}_{4}-\mathrm{N}$ & $\begin{array}{l}4.57 \mathrm{mg} \mathrm{O}_{2} / \mathrm{mg} \mathrm{NH}_{4}-\mathrm{N} \\
\begin{array}{llll}3.43 \mathrm{mg} & \mathrm{O}_{2} / & \mathrm{mg} & \mathrm{NH}_{4}-\mathrm{N} \\
\text { (nitritation) }\end{array}\end{array}$ & None. & $\begin{array}{l}\text { Consumed: } \\
7.1 \mathrm{mg} \mathrm{CaCO}_{3} / \mathrm{mg} \mathrm{NH}_{4}- \\
\mathrm{N} \\
7.1 \mathrm{mg} \mathrm{CaCO}_{3} / \mathrm{mg} \mathrm{NH}_{4}- \\
\mathrm{N} \text { (nitritation) }\end{array}$ & $\mathrm{NO}_{3}-\mathrm{N}$ \\
\hline & Partial nitrification (SHARON) & $\mathrm{NH}_{4}-\mathrm{N}$ & $3.43 \mathrm{mg} \mathrm{O}_{2} / \mathrm{mg} \mathrm{NH}_{4}-\mathrm{N}$ & None. & $\begin{array}{l}\text { Consumed: } \\
3.6 \mathrm{mg} \mathrm{CaCO}_{3} / \mathrm{mg} \mathrm{NH}_{4^{-}} \\
\mathrm{N}\end{array}$ & $\begin{array}{l}\mathrm{NH}_{4}-\mathrm{N} \\
\mathrm{NO}_{2}-\mathrm{N}\end{array}$ \\
\hline & Conventional denitrification & $\begin{array}{l}\mathrm{NO}_{3}-\mathrm{N} \\
\mathrm{NO}_{2}-\mathrm{N}\end{array}$ & None. & $\begin{array}{l}\text { For acetic acid: } \\
2.08-3.7 \quad \mathrm{mg} \\
\mathrm{COD} / \mathrm{mg} \mathrm{NO}_{3}-\mathrm{N} \\
1.56-2 \mathrm{mg} \mathrm{COD} / \mathrm{mg} \\
\mathrm{NO}_{2}-\mathrm{N}\end{array}$ & $\begin{array}{l}\text { Produced: } \\
3.6 \mathrm{mg} \mathrm{CaCO} / \mathrm{mg} \mathrm{NO}_{3}- \\
\mathrm{N}\end{array}$ & $\mathrm{N}_{2}$ \\
\hline & $\begin{array}{l}\text { Aerobic nitrifier denitrification in the presence of } \\
\mathrm{NO}_{\mathrm{X}}\left(\mathrm{NO}_{\mathrm{X}} \text { processes }\right)\end{array}$ & $\begin{array}{l}\mathrm{NH}_{4}-\mathrm{N} \\
\mathrm{NO}_{2}-\mathrm{N}\end{array}$ & $2.3 \mathrm{mg} \mathrm{O}_{2} / \mathrm{mg} \mathrm{NH}_{4}-\mathrm{N}$ & $\begin{array}{l}\text { Only for the } \\
\text { denitrification step }\end{array}$ & $\begin{array}{l}\text { Consumed: } \\
3.6 \mathrm{mg} \mathrm{CaCO}_{3} / \mathrm{mg} \mathrm{NH}_{4-} \\
\mathrm{N}\end{array}$ & $\begin{array}{l}\mathrm{NO}_{2}-\mathrm{N} \\
\mathrm{N}_{2}\end{array}$ \\
\hline & Anammox & $\begin{array}{l}\mathrm{NH}_{4}-\mathrm{N} \\
\mathrm{NO}_{2}-\mathrm{N}\end{array}$ & None. & None. & $\begin{array}{l}\text { Produced: } \\
3.3 \mathrm{mg} \mathrm{CaCO} / \mathrm{mg} \mathrm{NH}_{4}- \\
\mathrm{N}\end{array}$ & $\begin{array}{l}\mathrm{NO}_{3}-\mathrm{N} \\
\mathrm{N}_{2}\end{array}$ \\
\hline & $\begin{array}{l}\text { CANON (combination of partial nitrification and } \\
\text { Anammox) }\end{array}$ & $\mathrm{NH}_{4}-\mathrm{N}$ & $2.3 \mathrm{mg} \mathrm{O}_{2} / \mathrm{mg} \mathrm{NH}_{4}-\mathrm{N}$ & None. & $\begin{array}{l}\text { Consumed: } \\
3.68 \mathrm{mg} \quad \mathrm{CaCO}_{3} / \mathrm{mg} \\
\mathrm{NH}_{4}-\mathrm{N}\end{array}$ & $\begin{array}{l}\mathrm{NO}_{3}-\mathrm{N} \\
\mathrm{N}_{2}\end{array}$ \\
\hline & $\begin{array}{l}\text { OLAND/aerobic deammonification (combination } \\
\text { of partial nitrification and aerobic denitrification) }\end{array}$ & $\mathrm{NH}_{4}-\mathrm{N}$ & $\begin{array}{l}1.71 \quad \mathrm{mg} \quad \mathrm{O}_{2} / \mathrm{mg} \quad \mathrm{NH}_{4}-\mathrm{N} \\
(\mathrm{OLAND}) \\
2.3 \mathrm{mg} \mathrm{O} / \mathrm{mg} \mathrm{NH}_{4}-\mathrm{N} \text { (aerobic } \\
\text { deammoninfication) }\end{array}$ & None. & $\begin{array}{l}\text { Consumed: } \\
\text { 3.6 } \mathrm{mg} \mathrm{CaCO}_{3} / \mathrm{mg} \mathrm{NH}_{4^{-}} \\
\mathrm{N}(\mathrm{OLAND}) \\
\text { None (aerobic } \\
\text { denitrification) }\end{array}$ & $\begin{array}{l}\mathrm{NO}_{2}-\mathrm{N} \\
\mathrm{N}_{2}\end{array}$ \\
\hline
\end{tabular}




\section{CONCLUSIONS}

The long-term operation of the BPB reactor was characterized by stable but low relative removal efficiencies in terms of both $\mathrm{COD}(<20 \%)$ and $\mathrm{NH}_{4}-\mathrm{N}(<30 \%)$. Approximately $90 \%$ of the removal occurred in the upper part (section 1 and section 2) of the studied reactor and the development of a thick biofilm in these sections was explicitly associated with the availability of DO.

A special step-wise procedure was developed to calculate the elementary mass balances for substrate, $\mathrm{DO}, \mathrm{NH}_{4}-\mathrm{N}$ and alkalinity, and analyze the relationships between these variables in the expected nitrogen transformations under aerobic conditions (i.e. biomass assimilation and nitrification). However, the elementary mass balances could not explain all the ambiguous experimental results, especially in the latter phase of the experimental assays, and other pathways of nitrogen removal had to be involved.

In terms of revising the conventional nitrogen cycle and discovering the novel removal processes, many uncertainties have arisen about the nitrogen removal pathways occurring in biofilm systems, such as the studied BPB reactor. Therefore, further research should be planned using an interdisciplinary approach and combining expansion of the experimental procedures with the measurements of gaseous compounds $\left(\mathrm{NO}, \mathrm{N}_{2} \mathrm{O}, \mathrm{N}_{2}\right)$, development of mechanistic models of the newly discovered processes as well as identification of microbial groups through molecular analyses and fluorescent in situ hybridization (FISH).

\section{REFERENCES}

Ahn Y. (2006) Sustainable Nitrogen Elimination Biotechnologies: A Review. Process Biochemistry, 41, 1709-1721

Albuquerque, A. (2003) Contribution to the Study of Residual Carbon Removal in Downflow Biological Packed Beds. PhD thesis, University of Beira Interior, Covilha, Portugal, 469 pp. (in Portuguese)

APHA-AWWA-WEF (1999) Standard Methods for the Examination of Water and Wastewater. $20^{\text {th }}$ edition, American Public Health Association, Washington, DC, USA, 1325 pp.

Colliver, B.B., and Stephenson, T. (2000) Production of nitrogen oxide and dinitrogen oxide by autotrophic nitrifiers, Biotechnol. Adv. 18 (3), pp. 219-232.

Dang, J.; Harvey, D.; Lobbary, A. and Grady Jr, C. (1989) Evaluation of Biodegradation Kinetic with Respirometric Data. Res. J. Water Poll. Cont. Fed., 61(11/12), 1711-1721.

Garzon-Zuniga, M., Lessard, P., Aubry, G. and Buelna G. (2005) Nitrogen Elimination Mechanisms in an Organic Media Aerated Biofilter Treating Pig Manure. Environ. Technol., 26, 361-371.

Grady, C.P.L. Jr., Daigger G.T. and Lim H.C. (1999) Biological Wastewater Treatment. Second Edition, Revised and Expanded. Marcel Dekker, New York (USA).

Helmer, C. and Kunst, S. (1998) Simultaneous Nitrification/Denitrification in an Aerobic Biofilm System. Wat. Sci. Tech., 37(4-5), 183-187.

Helmer, C., Kunst, S., Juretschko, S., Schmid, M.C., Schleifer, K.H. and Wagner, M. (1999) Nitrogen Loss in a Nitrifying Biofilm System. Wat. Sci. Tech., 39(7), 13-21.

Helmer. C., Tromm, C., Hippen, A., Rosenwinkel, K.-H, Seyfried, C.F. and Kunst, S. (2001) Single Stage Biological Nitrogen Removal by Nitritation and Anaerobic Ammonium Oxidation in Biofilm Systems. Wat. Sci. Tech., 43 (1), 311-320.

Henze, M., Gujer W., Mino T. and van Loosdrecht M. (eds.) (2000) Activated Sludge Models ASM1, ASM2d and ASM3. Scientific and Technical Report No. 9. IWA Publishing, London (UK). 
Hidaka, T. and Tsuno, H (2004) Development of a Biological Filtration Model Applied for Advanced Treatment of Sewage. Wat. Res., 38, 335-346.

Jeong, J., Hidaka, T., Tsuno, H. and Oda, T. (2006) Development of Biological Filter as Tertiary Treatment for Effective Nitrogen Removal: Biological Filter for Tertiary Treatment. Wat. Res., 40, 1127-1136.

Jetten, M.S.M., Strous, M., Van De Pas-Schoonen, K.T., Schalk, J., Van Dongen, U.G.J.M., Van De Graaf, A.A., Logemann, S., Muyzer, G., Van Loosdrecht, M.C.M. and Kuenen, J.G. (1998) The anaerobic oxidation of ammonium. FEMS Microbiol. Rev., 22, 421-437.

Khin, T. and Annachhatre, A. (2004) Novel Microbial Nitrogen Removal Processes. Biotechnology Advances, 22, 519-532.

Littleton, H.X., Daigger, G.T., Strom, P.F. and Cowan, R.A. (2003) Simultaneous Biological Nutrient Removal: Evaluation of Autotrophic Denitrification, Heterotrophic Nitrification, and Biological Phosphorus Removal in Full-scale Systems. Wat. Env. Res., 75, 138-150.

Mulder A., van de Graaf A., Robertson L., Kuenen J. (1995) Anaerobic Ammonium Oxidation Discovered in a Denitrifying Fluidized Bed Reactor, FEMS Microbiol. Ecol., 16 (3), 177-184.

NF EN 29439 (1993) Qualité de l'eau. - Evaluation, en Milieu Aqueux, de la Biodégradabilité Aérobie "Ultime» des Composés Organiques. Homologuée le 20 avril 1993. Indice de classement: T90-306.

Paredes D., Kuschk P., Mbwette T., Stange F., Müller R. and Köser H. (2007) New Aspects of Microbial Nitrogen Transformations in the Context of Wastewater Treatment - A Review. Eng. Life Sci., 7 (1), 13-25.

Pynaert, K., Sprengers, R., Laenen, J. and Verstraete, W. (2002) Oxygen-limited Nitrification and Denitrification in a Lab-scale Rotating Biological Contactor. Environ. Technol., 23, 353-362.

Schmidt, I., Sliekers, O., Schmid, M., Bock, E., Fuerst, J., Kuenen, J.G., Jetten, M.S.M. and Strous, M. (2003) New Concepts of Microbial Treatment Processes for the Nitrogen Removal in Wastewater. FEMS Microbiol. Rev., 27, 481-492.

Siegrist, H., Reithaar, S., Koch, G. and Lais, P. (1998) Nitrogen Loss in a Nitrifying Rotating Contactor Treating Ammonium-rich Wastewater Without Organic Carbon. Wat. Sci. Tech., 38(8-9), 241-248.

Tchobanoglous, G., Burton, F.L., Stensel, H.D. (2003) Wastewater Engineering. Treatment and Reuse. 4th Edition, McGraw-Hill, New York.

van Loosdrecht, M.C.M. and Salem, S. (2005) Biological Treatment of Sludge Digester Liquids. Proceedings of the IWA Conference on Nutrient Management in Wastewater Treatment Processes and Recycle Streams, Cracow (Poland), 18-21 September 2005, 13-22.

Wanner, O., Eberl, H., Morgenroth, E., Noguera, D., Picioreanu, C., Rittmann, B. and van Loosdrecht, M (2006). Mathematical Modeling of Biofilms. Scientific and Technical Report No. 18. IWA Publishing, London (UK).

Yu, X., Qi, Z., Zhang, X., Yu, P., Liu, B., Zhang, L. and Fu, L. (2007) Nitrogen Loss and Oxygen Paradox in Full-scale Biofiltration for Drinking Water Treatment. Wat. Res., 41, 1455 - 1464. 